\title{
In Vitro Potential Cytotoxicity of an Adhesive System to Alveolar Macrophages
}

\author{
Isabel Cristina Celerino de Moraes PORTO ${ }^{1}$ \\ Ana Karina Maciel de ANDRADE ${ }^{2}$ \\ Gymenna Maria Tenório GUÊNES ${ }^{2}$ \\ Ana Isabella Arruda Meira RIBEIRO2 \\ Rodivan BRAZ2 \\ Célia Maria Machado Barbosa de CASTRO ${ }^{3}$
}

\author{
${ }^{1}$ Department of Restorative Dentistry, University of Pernambuco, Camaragibe, PE, Brazil; Health and Biological Science \\ School, University Center Cesmac, Maceió, AL, Brazil \\ ${ }^{2}$ Department of Restorative Dentistry, University of Pernambuco, Camaragibe, Pernambuco, PE, Brazil \\ ${ }^{3}$ Laboratory of Immunopathology "Keizo Asami", Federal University of Pernambuco, Recife, PE, Brazil
}

\begin{abstract}
The purpose of this study was to evaluate the potential cytotoxicity of Adper Single Bond 2 (SB) simplified etch-and-rinse adhesive system in alveolar macrophage cultures, as a function of the post-polymerization time and duration of immersion in the culture medium for preparation of extracts, by observing the levels of nitric oxide (NO) release and cell survival rate (MTT assay). Wistar rat alveolar macrophages were exposed to $200 \mu \mathrm{L}$ of extracts obtained from 24- or 72-h immersion of adhesive samples in culture medium (RPMI), immediately or $24 \mathrm{~h}$ after polymerization. Fresh RPMI and E. coli lipopolysaccharides were used as negative and positive controls, respectively. The cells were placed in a humidified incubator for $24 \mathrm{~h}$. The results were analyzed by the Student's-t test ( $\alpha=5 \%)$. The amount of NO produced and viable cells were significantly different $(p<0.05)$ between the experimental and the control groups, showing that, irrespective of the post-polymerization time and duration of immersion in the culture medium, the adhesive system caused intense cytotoxicity to the macrophages. The cytotoxic effects were not statistically different $(\mathrm{p}<0.05)$ among the experimental groups. In conclusion, chemical components released from SB in aqueous environment were highly toxic to cell culture and thus an inflammatory pulpal response should be considered during the clinical application of dental adhesives.
\end{abstract}

Key Words: cells, cytotoxicity, dentinal adhesives, macrophages.

\section{INTRODUCTION}

In the field of biomaterials, it is necessary to consider aspects of biosecurity, such as elimination of cytotoxicity and other harmful effects of the material to be used (1). By definition, the cytotoxicity of an agent means the toxicological risks caused by a material or its extract in a cell culture (2). The interactions of the materials and their components with the cells at a molecular level are responsible for tissue reactions, such as inflammation, necrosis (3), immunological alterations, genotoxicity (4) and apoptosis (5).

Dentin adhesive systems are widely used in clinical dental practice often before adverse effects on the pulp tissue have been studied (6). In vitro and in vivo studies have demonstrated that the cytotoxic effects of these systems depend on the amount of unreacted resin monomers, which can be influenced by various factors $(3,7)$, including the degree of conversion, which represents the number of double carbon bonds consumed during the chemical reaction $(8,9)$. Even under sufficient light intensity, an amount of residual monomer can be recorded (10).

Sano and Melo (11) observed that polymerization occurs after light irradiation, called post-cure polymerization, and that this occurs due to the free radicals remaining from light activation. In the first instance, they are highly reactive, and then half the unreacted 
radicals are converted into polymers within 1-2 days. The free monomers that remain after polymerization can be released into the saliva (12) or diffuse through the dentinal tubules towards the pulp (13), and are capable of causing inflammation of variable intensity, or even pulp necrosis (3).

Monomers such as 2-hydroxyethyl-methacrylate (HEMA) and triethyleneglycol dimethacrylate (TEGDMA) are commonly used as constituents of composites and other resinous materials, and have been identified in aqueous extracts derived from these materials (13).

The potential cell damage caused by monomers and other constituents of adhesive systems $(7,13,14)$ may vary from one material to another due to the differences in chemical composition, producing various effects on pulpal tissue (14). Therefore, it is necessary to assess the degree of cellular damage caused by these agents.

This study was developed to test the null hypothesis that cells cultured in contact with products released from samples of polymerized adhesive system cause damage in alveolar macrophages under the tested conditions. The aim of this research was to assess the potential cytotoxicity of a etch-and rinse adhesive system in rat alveolar macrophages, as a function of the postpolymerization time and duration of immersion in culture medium for preparation of extracts, by observing the levels of nitric oxide (NO) after stimulation by extracts and cell metabolic activity using the methyltetrazolium (MTT) assay.

\section{MATERIAL AND METHODS}

\section{Alveolar Macrophages and Cell Cultures}

Twenty male Wistar rats (Rattus norvegicus albinus) aged between 90 and 120 days were obtained from the vivarium of the Department of Nutrition of the Federal University of Pernambuco, Brazil, after approval of the research protocol by the local Animal Care and Research Use Committee (Protocol \#012258/2007-55). All guidelines regarding the care of animal research subjects were strictly followed in this study. The rats were housed in plastic cages and maintained under climatecontrolled conditions (12-h light/dark cycles; $22 \pm 1^{\circ} \mathrm{C}$ ). During the whole experimental period, the animals were fed solid rat chow (Labina, Purina do Brasil, Paulínia, SP, Brazil) and water ad libitum.

Before the surgical procedure, the animals were weighed and then anesthetized with an intraperitoneal injection of $12.5 \%$ urethane $(8 \mathrm{~mL} / \mathrm{kg}$ body weight $)$ and $0.4 \%$ chloralose administered. Bronchoalveolar lavage (BAL) was collected according to the methodology described by De Castro et al. (15), with saline at room temperature, by means of a syringe coupled to a plastic cannula inserted in the trachea of each animal. Several $3-\mathrm{mL}$ aliquots of solution were injected, aspired and collected until a final volume of $30 \mathrm{~mL}$ was obtained. After BAL collection, the solution was centrifuged and the supernatants were discarded. The precipitate, which corresponded to the cells, was resuspended in $2 \mathrm{~mL}$ of Roswell Park Memorial Institute culture medium (RPMI1640; Gibco, Invitrogen Corp., Carlsbad, CA, USA) containing bovine fetal serum (BFS; Gibco, Invitrogen Corp.), penicillin (100 U/mL), streptomycin $(100 \mu \mathrm{g} / \mathrm{mL})$ and amphotericin B $(0.25 \mu \mathrm{g} / \mathrm{mL}$; Gibco, Invitrogen Corp.).

The cells were counted in a Newbauer chamber after 1:10 dilution with Trypan Blue dye $(10 \mu \mathrm{L}$ of cells in $90 \mu \mathrm{L}$ of Trypan Blue). As Trypan Blue stains the dead cells, but not the lives ones, it can be used to assess viability while counting the cells.

The cells $\left(2 \times 10^{6}\right.$ cells $/ 2 \mathrm{~mL}$ of RPMI1640 per well) were transferred to the culture plate (Falcon; Sigma-Aldrich, Munich, Germany) and incubated for $1 \mathrm{~h}$ at $37^{\circ} \mathrm{C}$ in $5 \% \mathrm{CO}_{2}$ and $95 \%$ air to stabilize the cells (Sanyo $\mathrm{CO}_{2}$ Incubator; Sanyo Electric Biomedical Co. Ltd., Osaka, Japan).

Preparation of the Adhesive Samples and their Extracts

Adper Single Bond 2 (SB) simplified etch-andrinse adhesive system was used in this study. This material has the following composition: HEMA, bis-GMA, ethanol, water, amines, camphoroquinone, dimethacrylate, functional methacrylate copolymer of polyacrylic and polyalkenoic acids and silica nanoparticles. Adhesive system samples were obtained by dripping the adhesive into a cylindrical polytetrafluoroethylene matrix ( $5 \mathrm{~mm}$ in internal diameter $\mathrm{x} 2 \mathrm{~mm}$ high) placed on a glass slide and light activated, only on the top face, for $20 \mathrm{~s}$ with a halogen light source (Optilux 401, Demetron; Kerr Corp., Orange, CT, USA; irradiance of $600 \mathrm{~mW} / \mathrm{cm}^{2}$ ) keeping the light guide tip in contact with the matrix, and gauged with a radiometer (Demetron/ Kerr, CT, USA) after every 5 samples made.

The extracts were prepared by immersing the 
adhesive samples in RPMI1640 in accordance with the ISO 10993-12 standard. Half of them were immersed in the culture medium immediately $(0 \mathrm{~h})$ and the other half $24 \mathrm{~h}$ after polymerization, and they remained in the culture medium for either $24 \mathrm{~h}$ or $72 \mathrm{~h}$, giving rise to four experimental groups (A, B, C and D). The negative control group received only plain RPMI1640 and the positive control group was stimulated with $E$. coli lipopolysaccharides (LPS) (Table 1).

The samples were removed from the culture medium after the recommended time and the extracts were filtered $(0.22 \mu \mathrm{m}$ filter; Millipore, Molsheim, France) to guarantee sterile conditions.

\section{Exposure of Macrophages to the Extracts}

Six replicates of $2 \mathrm{~mL}$ aliquots of RPMI 1640 with macrophages $\left(2 \times 10^{6}\right.$ of cells/well) were seeded on 6 -well culture plates (Falcon, Sigma-Aldrich) with the addition of $200 \mu \mathrm{L}$ of extract without dilution $(100 \%$, experimental groups (A, B, C and D) (Table 1), $200 \mu \mathrm{L}$ of culture medium (negative control group) or $20 \mu \mathrm{L}$ of LPS (positive control group); the plates were then kept in an incubator at $37^{\circ} \mathrm{C}$ in $5 \% \mathrm{CO}_{2}$ and $95 \%$ air.

\section{Determination of Nitric Oxide Levels and Cell Viability}

After incubation for $24 \mathrm{~h}$, the supernatant macrophages were collected and $\mathrm{NO}$ production was measured in a spectrophotometer (Ultrospec 3000 Pro; Biochron Ltd, Cambridge, UK) by the absorbance at $540 \mathrm{~nm}$ wavelength. The nitrite/nitrate concentration, an indirect measurement of $\mathrm{NO}$ synthesis, was calculated using the standard $\mathrm{NaNO}_{2}$ curve and the data were expressed in $\mu \mathrm{M} / \mathrm{mL}$ of nitrite/nitrate.

Cell viability was assessed by the cytochemical demonstration of succinic dehydrogenase (SDH) enzyme activity, which is a measure of the mitochondrial

Table 1. Distribution of experimental groups.

\begin{tabular}{ccc}
\hline $\begin{array}{c}\text { Experimental } \\
\text { group }\end{array}$ & $\begin{array}{c}\text { Post-polymerization } \\
\text { time }(\mathrm{h})\end{array}$ & $\begin{array}{c}\text { Time in culture } \\
\text { medium }(\mathrm{h})\end{array}$ \\
\hline $\mathrm{A}$ & 0 & 24 \\
$\mathrm{~B}$ & 24 & 24 \\
$\mathrm{C}$ & 0 & 72 \\
$\mathrm{D}$ & 24 & 72 \\
\hline
\end{tabular}

respiration of the cells, employing the MTT assay, as follows. A plate with cell culture was taken from the autoclave after the incubation period. The supernatant was discarded and the monolayer of cells was washed with $1 \mathrm{~mL}$ of phosphate buffered saline solution (PBS) at room temperature. Then, $550 \mu \mathrm{L}$ of PBS and $55 \mu \mathrm{L}$ of MTT solution were added. The solution was homogenized and the culture plates placed in the incubator for $2 \mathrm{~h}$ under the same conditions in which the cells were cultivated. After this period, the supernatant was discarded and replaced by $200 \mu \mathrm{L}$ of PBS and $200 \mu \mathrm{L}$ of DMSO to dissolve the formazan salt formed in the presence of mitochondrial activity. The optical density of the solutions was determined with a spectrophotometer at $570 \mathrm{~nm}$ (Ultrospec 3000 Pro; Biochron Ltd, Cambridge, UK). The mean absorption of each group was calculated and expressed as SDH enzyme activity, and compared with the negative control group.

\section{Statistical Analysis}

Statistical analysis to determine the differences among the groups was performed using Student's-t test at $5 \%$ significance level using SPSS version 11.0 (SPSS Inc., Chicago, IL, USA).

\section{RESULTS}

The results of the two tests - NO dosage and cell viability (MTT assay) (Figs. 1 and 2 respectively) showed that the bonding agents had intense cytotoxic effects. There was statistically significant difference $(p<0.05)$ between the experimental and control (positive and negative) groups. In the experimental groups, the cytotoxicity of SB in alveolar macrophages showed slight variation dependent on the post-polymerization time and was greater with extracts of freshly cured samples, but did not differ significantly ( $p>0.05)$. The different extraction times did not have a significant effect $(\mathrm{p}>0.05)$ on the SDH enzyme activity ( $\mathrm{p}>0.05)$. The extracts obtained after $24 \mathrm{~h}$ of leaching caused lower reduction of viable cells (46 and 67\%) than those extracted at $72 \mathrm{~h}(82$ and $79 \%)$. After contact with LPS (positive control) cellular activity was reduced 17\%.

There were no significant differences $(p>0.05)$ in the NO levels produced by macrophages stimulated with any extracts. A significantly lower NO production was found for all experimental groups compared to groups 
controls $(\mathrm{p}<0.05)$ after $24 \mathrm{~h}$ of exposure to the extracts.

\section{DISCUSSION}

In the oral mucosa, innate immunity is mediated by the epithelial barrier, circulating cells and proteins that act by recognizing the aggressor substance. Phagocytic cells, such as the macrophages, are among the components of innate pulpal immunity (16). Macrophages perform a well-known function in inflammatory response, and are therefore indicated for testing dental materials in vitro. These cells seem to be more sensitive to tests than those of the immortalized cell lines. All these features provided the basis and justified the choice of alveolar macrophages for testing the potential cellular damage of the Adper Single Bond 2 adhesive system.

The macrophages are activated in the initial stages of pulpal inflammation (16) and can produce NO in response to harmful stimuli. In this study, the mean nitric oxide level of the test groups was significantly lower than that of the positive and negative control groups. This possibly represents a high level of cell death, and consequently, the intense cytotoxic effect of the test material, which could be accredited to the high concentration of residual products released into the culture medium. On the other hand, low concentrations of NO may have been caused by changes in normal cells functions, including NO generate, and may indicate a

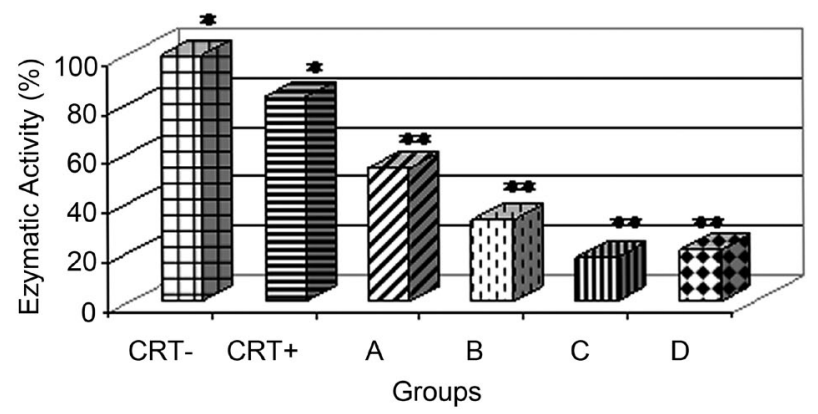

Figure 1. Cell viability after $24 \mathrm{~h}$ in contact with the extracts obtained from immediate immersion of the polymerized adhesive in the culture medium (groups A and C) and immersion $24 \mathrm{~h}$ after polymerization (groups B and D). The period of lixiviation was 24 $\mathrm{h}$ (groups A and B) or $72 \mathrm{~h}$ (groups $\mathrm{C}$ and D). The negative control group (CRT-) received pure culture medium and the positive control group (CRT+) LPS. Groups with different symbols $(*)$ indicate statistically significant differences $(p<0.05)$. reduced ability to respond to noxious stimuli, as solutions containing leachable agents from dental adhesives.

The pattern of apoptotic response, cellular glucose, oxygen consumption and gene expression after exposure to the various adhesive compounds has been used to evaluate cytotoxicity in previous studies $(12,17,20)$ and can be used to assess cytopathic effects of multicomponent extracts from cured dental adhesives such as used in this study. The use of different methods to evaluate the cytotoxicity of dental materials may results in data that's enables to provide a knowledge base able to clarify how dentin adhesive affects cell behavior.

Oral cells can be directly exposed to polymers used in dentistry, when dental materials come in contact with gingival tissue, or indirectly when products release from the polymers migrate towards the pulpal or surrounding tissues. The results of this study are in agreement with previous in vitro investigations in which the cytotoxicity of resinous components was evaluated using the MTT assay $(7,17)$. The extracts obtained from the Adper Single Bond 2 adhesive system were capable of reducing cellular viability in macrophages in vitro, ratifying the study of Becher et al. (17).

Studies have shown that HEMA and TEGDMA released from resin dental materials have a cytotoxic action $(7,17)$. TEGDMA has been described as being more toxic than HEMA in the MTT assay (17). However, Falconi et al. (7) warned that low concentrations of HEMA could significantly alter the morphology of cells, such as human gingival fibroblasts. This information is important for our experiment because SB contains HEMA and dimethacrylate.

In a previous study (14), the adhesive systems

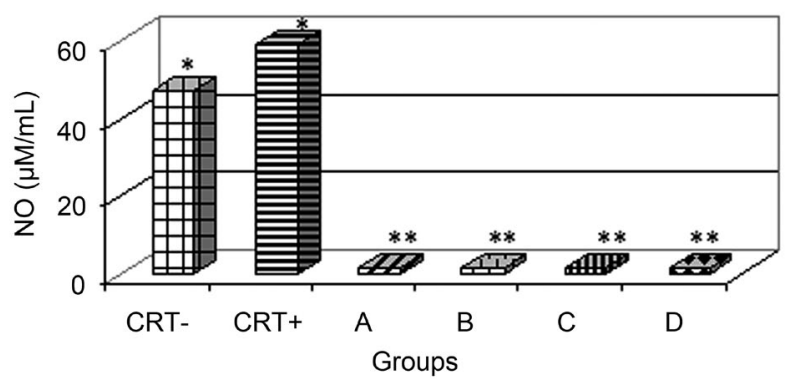

Figure 2. Nitric oxide production after macrophages were stimulated with extracts, LPS (CRT + ) and pure culture medium (CRT-). Groups with different symbols (*) indicate statistically significant differences $(\mathrm{p}<0.05)$. 
evaluated under different culture protocols were cytotoxic to human pulpal cells. The authors alleged that the cause of this cytotoxicity was the presence of substances that can be lixiviated from these materials, and that dentin could be an important pulp protector, in addition to pulp circulation, which reduces the concentration of harmful agents. The results of the present study are in agreement with the findings of those authors because one of the adhesives used by them, Single Bond, is a precursor of the SB used in our research. Both materials affected cell viability, although they were tested in different cell cultures.

On the other hand, the results of the present study differ from those obtained by Kostoryz et al. (18) who observed that aged extracts did not affect cell viability, and only the polymerization time caused damage. In their study, the extracts were obtained after immersion of the adhesive samples in the culture medium for 16 weeks, a much longer time than the one used in our experiment.

The extracts used in the present study were obtained by immersing the samples in the culture medium for either 24 or $72 \mathrm{~h}$, which is a sufficient period for $85 \%$ of the unreacted monomer Bis-GMA to be released (19). Considerable reduction in the substances capable of being lixiviated was recorded around the 7th day of immersion (20); this could indicate that in this period, complete lixiviation of the free monomers does not occur (19). Although these substances can still be detected after 7 days, cellular viability is not affected by the extracts at 5 or more days (20).

It is important to emphasize that the amount of adhesive used to fabricate the samples in this experiment was larger than the amount used in clinical practice, when the adhesive is applied in layers, and the composite is then added and light activated, which possibly provides additional polymerization of the adhesive (18). Furthermore, if the level of cytotoxicity of the material does not exceed the organism's defense capacity, it can be considered as acceptable. Nevertheless, irritation of dental pulp by leachable components of the dentin adhesives should be considered during clinical application of these materials.

The results obtained in this study indicate that irrespective of the post-polymerization time and the duration of immersion in the culture medium, SB caused to intense cytotoxicity to the stimulated macrophage culture. Therefore, further studies must be conducted in vivo to approximate the clinical conditions of adhesive system application and the physiologic reactions, such as pulp circulation, which attenuate the cytotoxic potential of dental materials.

\section{RESUMO}

O objetivo deste estudo foi avaliar o potencial de citotoxicidade do sistema adesivo Adper Single Bond 2 (SB), em função dos tempos pós-polimerização e imersão no meio de cultura para preparação dos extratos, observando-se os níveis de liberação de óxido nítrico (NO) e taxa de sobrevivência celular (MTT assay). Macrófagos alveolares de ratos Wistar foram expostos a $200 \mu \mathrm{L}$ de extratos obtidos a partir da imersão de amostras do adesivo em meio de cultura (RPMI), imediatamente ou $24 \mathrm{~h}$ após sua polimerização, onde permaneceram durante 24 ou $72 \mathrm{~h}$. RPMI puro e lipopolissacarídeos de E. coli foram utilizados como controles negativo e positivo, respectivamente. As células foram levadas à incubadora umidificada por $24 \mathrm{~h}$. Os resultados foram submetidos ao teste "t" de Student $(\alpha=5 \%)$. As quantidades de NO produzido e células sobreviventes foram significativamente diferentes entre os grupos experimentais e grupos controle, mostrando que, independente do tempo pós-polimerização e tempo de elaboração dos extratos, o sistema adesivo causou uma intensa citotoxicidade sobre os macrófagos. Os efeitos citotóxicos não foram estatisticamente diferentes entre os grupos experimentais. Componentes químicos do SB liberados em meio aquoso podem ser altamente citotóxicos para as células em cultura e, portanto, uma resposta inflamatória pulpar deve ser considerada durante a aplicação clínica de adesivos dentinários.

\section{REFERENCES}

1. Kirkpatrick CJ, Peters K, Hermanns MI, Bittinger F, KrumpKonvalinkova V, Fuchs S, et al.. In vitro methodologies to evaluate biocompatibility: status quo and perspective. ITBM 2005;26:192199.

2. Cao T, Saw TY, Heng BC, Liu H, Yap AU, Ng ML. Comparison of different test models for assessment of cytotoxicity of composites resins. J Appl Toxicol 2005;25:101-108.

3. Accorinte MLR, Loguercio AD, Reis A, Muench A, Araújo VC. Adverse effects of human pulps after direct pulp capping with the different components from a total-etch three-step adhesive system. Dent Mater 2005;21:599-607.

4. Kleinsasser NH, Wallner BC, Harréus UA, Kleinjung T, Folwaczny M, Hickel R, et al.. Genotoxicity and cytotoxicity of dental materials in human lymphocytes as assessed by the single cell microgel electrophoresis (comet) assay. J Dent 2004;32:229-234.

5. Paranjpe A, Bordador LC, Wang MY, Hume WR, Jewett A. Resin monomer 2-hydroxyethyl methacrylate (HEMA) is a potent inducer of apoptotic cell death in human and mouse cells. J Dent Res 2005;84:172-177.

6. Costa CAS, Hebling J, Hanks CT. Current status of pulp capping with dentine adhesive systems - a review. Dent Mater 2000;16:188-197.

7. Falconi M, Teti G, Zago M, Pelotti S, Breschi L, Mazzotti G. Effects of HEMA on type I collagen protein in human gingival fibroblasts. Cell Biol Toxicol 2007;23:313-322.

8. Giannini M, Arrais CA, Vermelho PM, Reis RS, dos Santos LP, Leite ER. Effects of the solvent evaporation technique on the 
degree of conversion of one-bottle adhesive systems. Oper Dent $2008 ; 33: 149-154$

9. Arrais CAG, Pontes FM, Santos LPS, Leite ER, Giannini M. Degree of conversion of adhesive systems light-cured by LED and halogen light. Braz Dent J 2007;18:54-59.

10. Franz A, König F, Lucas T, Watts DC, Schedle A. Cytotoxicity of dental bonding substances as a function of degree of conversion. Dent Mater 2009; 25:232-239.

11. Sano W, Melo CBM. Hardness of dental composite resins and free radical quantity determination by ESR. Rev Bras Engenh Biomed 1999;15:17-20.

12. Nocca G, De Palma F, Minucci A, De Sole P, Martorana GE, Callà $\mathrm{C}$, et al.. Alterations of energy metabolism and glutathione levels of HL-60 cells induced by methacrylates present in composite resins. J Dent 2007;35:187-194.

13. Çetingüç A, Ölmez S, Vural N. HEMA diffusion from dentin bonding agents in young and old primary molars in vitro. Dent Mater 2007;23:302-307.

14. Huang FM, Chang YC. Cytotoxicity of dentine-bonding agents on human pulp cells in vitro. Inter Endod J 2002;35:905-909.

15. De Castro CMMB, Bureau MF, Nahori MA, Dumary $\mathrm{CH}$,
Vargaftig BB, Bachilet M. Modulation by dexamethasone of phospholipase $A_{2}$ activities in endotoxemic guinea pigs. J Appl Phys 1995;79:1271-1277.

16. Hahn CL, Liewehr FR. Innate immune responses of the dental pulp to caries. J Endod 2007;33:643-651.

17. Becher R, Kopperud HM, Al RH, Samuelsen JT, Morisbak E, Dahlman HJ, et al.. Pattern of cell death after in vitro exposure to GDMA, TEGDMA, HEMA and two compomer extracts. Dent Mater 2006;22:630-640.

18. Kostoryz EL, Eick JD, Chappelow CC, Glaros AG, Wetmore L, Yourtee DM. In vitro effect of light-cure dental adhesive on IL-6 release from LPS- stimulated and unstimulated macrophages. J Biomed Mater Res 2003;65:89-94.

19. Nalçaci A, Ulusoy N, Atakol O. Time-based elution of TEGMA and BisGMA from resin composite cured with LED, QTH and high intensity QTH light. Oper Dent 2006;31:197-203.

20. Lin NJ, Bailey LO, Becker MI, Washburn NR, Henderson LA. Macrophage response to methacrylate conversion using a gradient approach. Acta Biomater 2007;3:163-173.

Accepted August 11, 2009 